\title{
Aeroheating measurement of Apollo shaped capsule with boundary layer trip in the free-piston shock tunnel HIEST
}

\author{
TANNO Hideyuki ${ }^{*}$, KOMURO Tomoyuki $^{\dagger}$, SATO Kazuo ${ }^{\dagger}$, ITOH Katsuhiro ${ }^{\star}$ \\ Japan Aerospace Exploration Agency, Kakuda Space Center, \\ Kakuda Miyagi JAPAN 981-1525 \\ Randolph P. Lillard ${ }^{\S}$ \\ NASA Johnson Space Center, Houston, TX 77058 \\ Joseph Olejniczak \\ NASA Ames Research Center, Moffett Field, CA 94035
}

Key Words : Aeroheating, Heat flux, Boundary layer transition, Hypersonic flow, Shock tunnel

\begin{abstract}
An aeroheating measurement test campaign of an Apollo capsule model with laminar and turbulent boundary layer was performed in the free-piston shock tunnel HIEST at JAXA Kakuda Space Center. A $250 \mathrm{~mm}$-diameter 6.4\%-scaled Apollo CM capsule model made of SUS-304 stainless steel was applied in this study. To measure heat flux distribution, the model was equipped with 88 miniature co-axial Chromel-Constantan thermocouples on the heat shield surface of the model. In order to promote boundary layer transition, a boundary layer trip insert with 13 "pizza-box" isolated roughness elements, which have $1.27 \mathrm{~mm}$ square, were placed at $17 \mathrm{~mm}$ below of the model geometric center. Three boundary layer trip inserts with roughness height of $\mathrm{k}=0.3 \mathrm{~mm}, 0.6 \mathrm{~mm}$ and $0.8 \mathrm{~mm}$ were used to identify the appropriate height to induce transition. Heat flux records with or without roughness elements were obtained for model angles of attack $28^{\circ}$ under stagnation enthalpy between $\mathrm{H}_{0}=3.5 \mathrm{MJ} / \mathrm{kg}$ to $21 \mathrm{MJ} / \mathrm{kg}$ and stagnation pressure between $P_{0}=14 \mathrm{MPa}$ to $60 \mathrm{MPa}$. Under the condition above, Reynolds number based on the model diameter was varied from 0.2 to 1.3 million. With roughness elements, boundary layer became fully turbulent less than $H_{0}=9 \mathrm{MJ} / \mathrm{kg}$ condition. However, boundary layer was still laminar over $\mathrm{H}_{0}=13 \mathrm{MJ} / \mathrm{kg}$ condition even with the highest roughness elements. An additional experiment was also performed to correct unexpected heat flux augmentation observed over $\mathrm{H}_{0}=9 \mathrm{MJ} / \mathrm{kg}$ condition.
\end{abstract}

\footnotetext{
*Associate Senior Researcher, Space Transportation Propulsion Research and Development Center, Space transportation mission directorates, tanno.hideyuki@jaxa.jp, AIAA member

${ }^{\dagger}$ Associate Senior Researcher, Space Transportation Propulsion Research and Development Center, Space transportation mission directorates

${ }^{\ddagger}$ Deputy Manager, Space Transportation Propulsion Research and Development Center, Space transportation mission directorates, AIAA member

${ }^{\S}$ Deputy Chief, Applied Aeroscience and Computation Fluid Dynamics branch, Johnson Space Center,

"Research Scientist, Reacting Flow Environments Branch, Ames Research Center, AIAA member
} 


\section{Nomenclature}

$\begin{array}{ll}H & =\text { Enthalpy } \\ P & =\text { Pressure } \\ T & =\text { Temperature } \\ \rho & =\text { Density } \\ u & =\text { Velocity } \\ \operatorname{Re} & =\text { Reynolds number } \\ \mathrm{D} & =\text { Model diameter }(250 \mathrm{~mm}) \\ \dot{q} & =\text { heat flux } \\ \text { St } & =\text { Stanton number }\left(\frac{\dot{\mathrm{q}}}{\rho \mathrm{uH}}\right)\end{array}$

\author{
Subscripts \\ $=$ Stagnation condition \\ $=$ Free-stream condition
}

\section{Introduction}

$T^{3}$ ypical design of thermal protection system for reentry vehicles based on aerodynamic heating with fully turbulent boundary layer. However, precise numerical prediction is still a significant technical issue due to lack of high-quality experimental data as a benchmark for turbulent model validation. Although large number of turbulent aeroheating experiments was reported in cold hypersonic wind tunnel, the number of experimental data in hot hypersonic flow is quite limited with too few ground test facilities. In JAXA, a wind tunnel test campaign was conducted to provide a benchmark data to validate numerical codes of aeroheating for capsule shaped reentry vehicles. The free-piston type high-enthalpy shock tunnel HIEST ${ }^{1}$ (Fig.1) has used for this test campaign, which tunnel can produce stagnation pressure up to $150 \mathrm{MPa}$ and stagnation enthalpies up to $10000 \mathrm{~K}$. At the maximum stagnation condition, the test duration is $2 \mathrm{~ms}$ or longer. With the HIEST contoured nozzle of exit diameter $800 \mathrm{~mm}$, it is possible to use test models with diameter up to $300 \mathrm{~mm}$. As shown in the HEST operation envelope (Fig.2), unit Re number easily exceed $4 \times 10^{6}$ at $\mathrm{H}_{0}=15 \mathrm{MJ} / \mathrm{kg}$. Based on typical model diameter in HIEST, it should be sufficient Re number for boundary layer transition.

However, even with maximum stagnation pressure in HIEST, it is distinctly impossible to produce sufficient Re number flow for natural transition over $\mathrm{H}_{0}=20 \mathrm{MJ} / \mathrm{kg}$. In addition, it is also not realistic from the viewpoint of operation cost to conduct extensive number of shots at maximum pressure to obtain turbulent aeroheating data.

As a solution of the above issue, JAXA started the study about protuberance to induce boundary layer transition through collaboration with NASA. In this paper, the latest results of aeroheating wind tunnel tests with a $6.4 \%$ scaled Apollo CM test model were reported in both laminar and transition boundary layers. To measure heat flux around the model, eighty-eight miniature co-axial thermocouples were mounted on the heat shield surface of the model. To trigger the onset of boundary layer transition, isolated roughness elements of pizza-box shaped a boundary layer trip insert, which have $1.27 \mathrm{~mm}$ square, were placed at $17 \mathrm{~mm}$ below of the model geometric center. Three boundary layer trip inserts with roughness height of $\mathrm{k}=0.3 \mathrm{~mm}, 0.6 \mathrm{~mm}$ and $0.8 \mathrm{~mm}$ were used to identify the appropriate height to induce transition. Heat flux records with or without roughness elements were obtained for model angles of attack $28^{\circ}$ under stagnation enthalpy between $\mathrm{H}_{0}=3.5 \mathrm{MJ} / \mathrm{kg}$ to $21 \mathrm{MJ} / \mathrm{kg}$ and stagnation pressure between $\mathrm{P}_{0}=14 \mathrm{MPa}$ to $60 \mathrm{MPa}$. Under

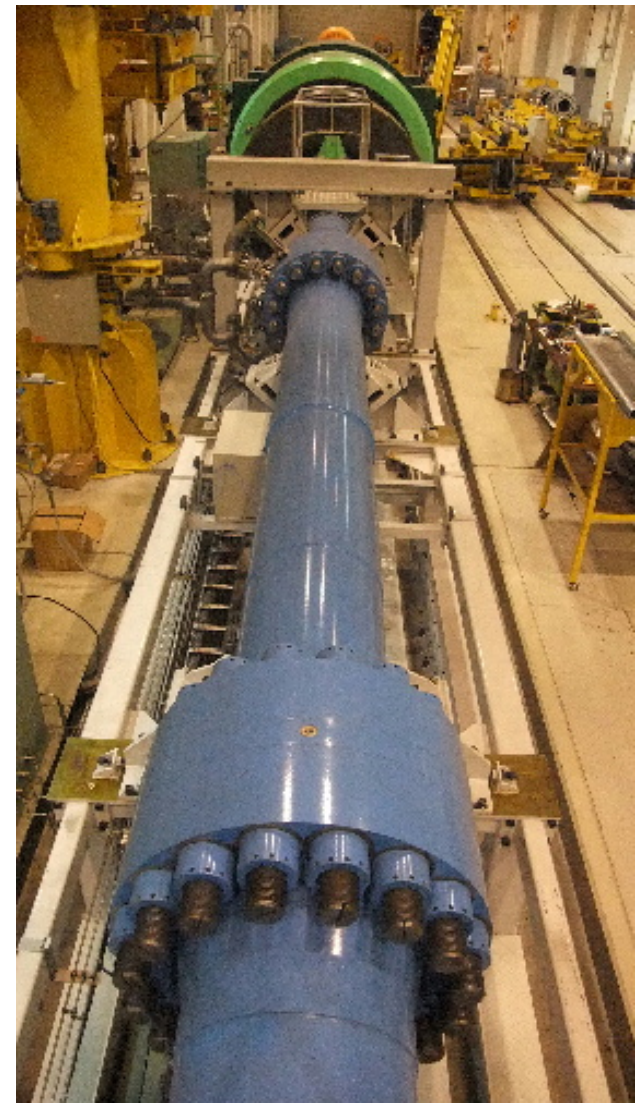

Fig.1 Shock tube and inertia mass of the freepiston shock tunnel HIEST. 
the condition above, Reynolds number based on the model diameter $(250 \mathrm{~mm})$ was varied from 0.2 to 1.3 million. The measured heat flux and effectiveness of the isolated roughens in particular roughness height were discussed. Moreover, an experimental trial to correct unexpected heat flux augmentation, which are observed in major shock tunnels, was also conducted. From the simple radiation heating measurement with a flat plate model, correlated parameter to correct augmentation was obtained for the heat flux measurement in HIEST.

\section{Experimental setup}

\section{A. Free-piston shock tunnel HIEST}

Fig.1 was a picture of the free-piston shock tunnel HIEST taken from the test section. This tunnel was originally built to obtain aerothermodynamic characteristics of the Japanese reentry vehicle HOPE. The tunnel can produce higher-stagnation conditions and longer test time than any other free-piston facility because it was basically designed to operate in a 'tuned' condition $^{2}$. The tunnel can be operated at stagnation pressures up to $150 \mathrm{MPa}$ and stagnation enthalpies up to $25 \mathrm{MJ} / \mathrm{kg}$ with the test time of $2 \mathrm{~ms}$ or longer. In the present test campaign, the HIEST contoured nozzle of $2.8 \mathrm{~m}$ long and with an exit diameter of $800 \mathrm{~mm}$ was used, which nozzle flow calibration were discussed in the previous report ${ }^{3}$. From $\mathrm{H}_{0}=3.5 \mathrm{MJ} / \mathrm{kg}$ to $\mathrm{H}_{0}=20 \mathrm{MJ} / \mathrm{kg}$, the nozzle calibration tests showed that a steady test core flow diameter prevailed up to $400 \mathrm{~mm}$, in which the deviation of the free-stream Pitot pressure was less than $6 \%$. Since the test duration depends on the stagnation condition, the test duration is $7 \mathrm{~ms}$ or longer under low-enthalpy condition $\left(\mathrm{H}_{0}\right.$ $=3.5 \mathrm{MJ} / \mathrm{kg}$ or lower). Relation of free-stream Re number and stagnation enthalpy with HIEST contoured nozzle was shown in Fig.2.
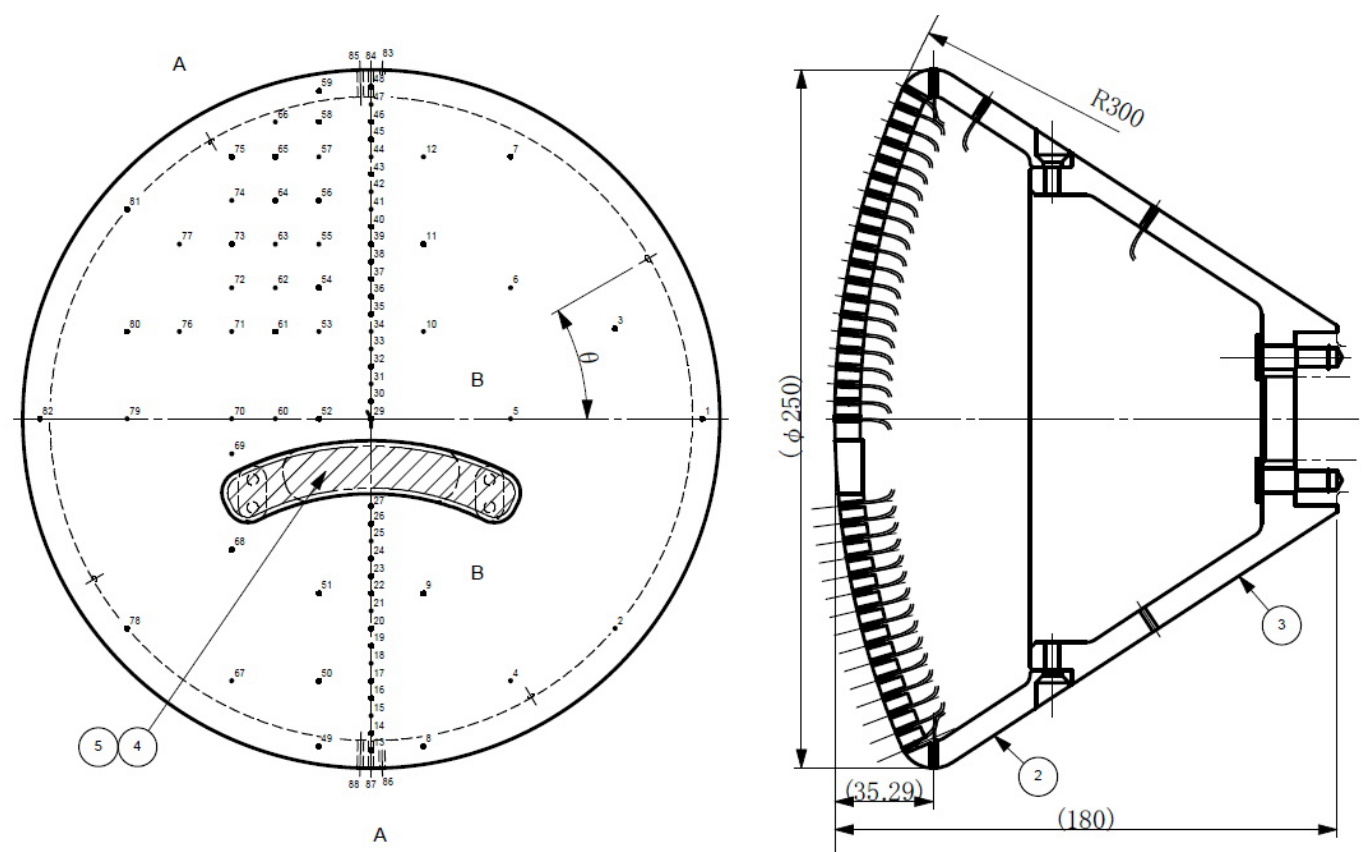

Fig.3 A drawing of the 6.4\% scaled (250mm diameter) Apollo CM test model. The numbers on the left figure indicate thermocouples mounted on the heat shield surface. 

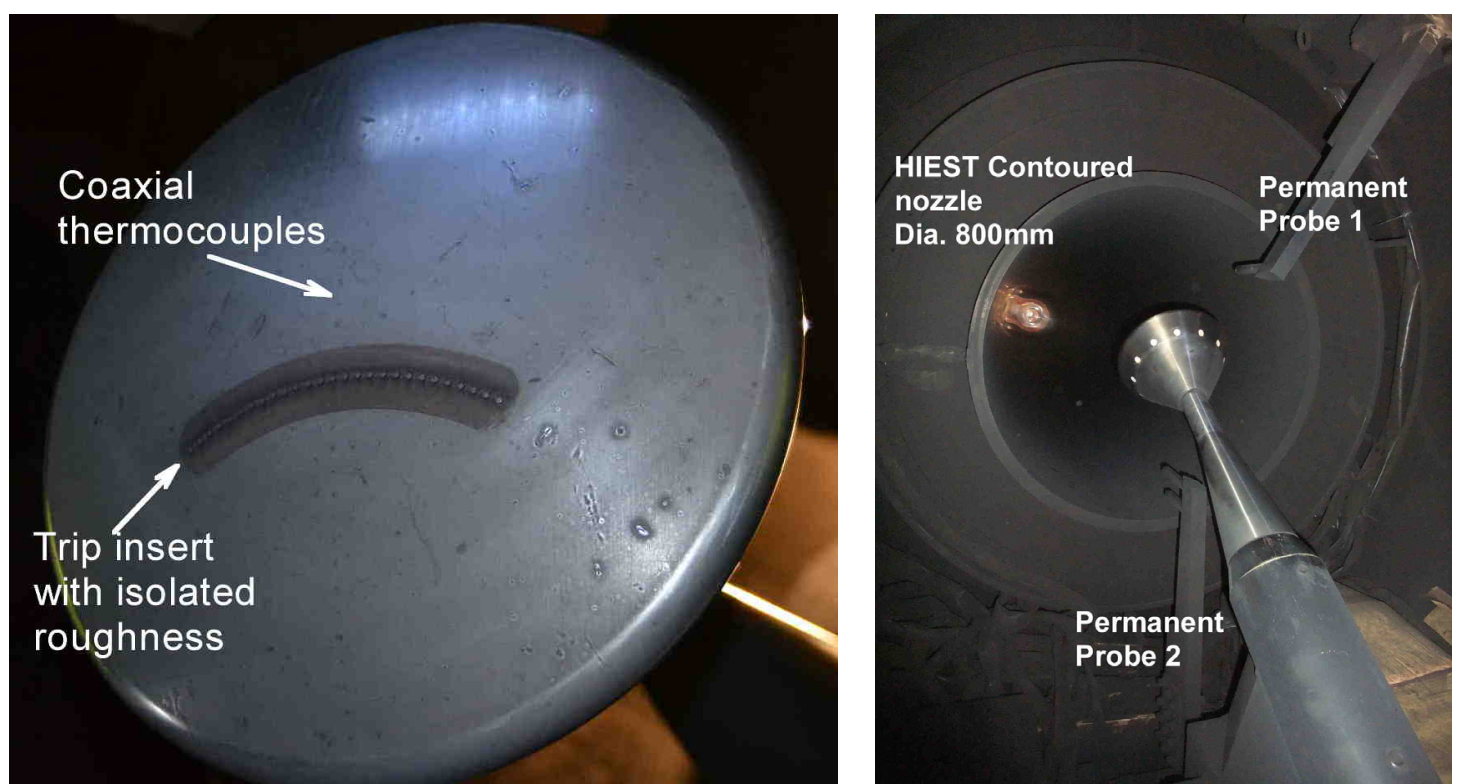

Fig.4 Left: Heat shield surface of Apollo CM test model with 'pizza-box' shaped isolated roughness elements $(\mathrm{k}=\mathbf{0 . 3 \mathrm { mm } )}$ on a trip insert. Right: Photo of Apollo CM test model installed in the HIEST test section.

HIEST has 128 DC amplifiers dedicated to the thermocouples. All outputs from the amplifiers are stored in a 14bit ADC with transient memory (System Design Service-Corp. Grasper model-1000) through signal conditioners (KYOWA Corp. CDV-700). The sampling frequency of the transient memory is $1 \mathrm{MHz}$, with resolution and recording duration of 16 bit and $200 \mathrm{~ms}$, respectively.

\section{B. Test model}

The geometry data of the Apollo CM test model shown in the Fig. 3 was obtained from the reference ${ }^{4}$. The diameter of Apollo CM test model applied in the test campaign was $250 \mathrm{~mm}$, which scale was almost $6.4 \%$ of the real flight vehicle. On the windward surface of the model, 88 co-axial miniature thermocouples were mounted, and on the leeward surface of the model, 12 co-axial miniature thermocouples and two Kulite Piezoresistive pressure transducers were mounted (not shown in the figure). The thermocouple originally developed in CalTech was Chromel-Constantan with its diameter $2.0 \mathrm{~mm}$. Location of the forebody thermocouples (shown as numbers in the figure), was provided from the reports for CEV Orion capsules ${ }^{5,6,7,8}$. The left picture of Fig.4 shows the heat shield surface of the Apollo CM test model. Coaxial thermocouples can be found as dots on the surface. The Right picture of the figure showed the model installed in the HIEST test section with angle of attack $28^{\circ}$. To monitor the test free-stream, there are two permanent probes (Pitot pressure probe and heat flux probe) in the HIEST test section. Both of the two permanent probes are located $250 \mathrm{~mm}$ from the nozzle center.

\section{Boundary layer trip insert}

In the whole of the present test campaign, boundary layer transition is not expected for all test flow condition except $\mathrm{H}_{0}=3.5 \mathrm{MJ} / \mathrm{kg}$ condition. Isolated roughness element has hence required to promote boundary layer transition on the leeside of the heat shield. The roughness elements used was 'pizza-box' shaped isolated roughness elements, which was

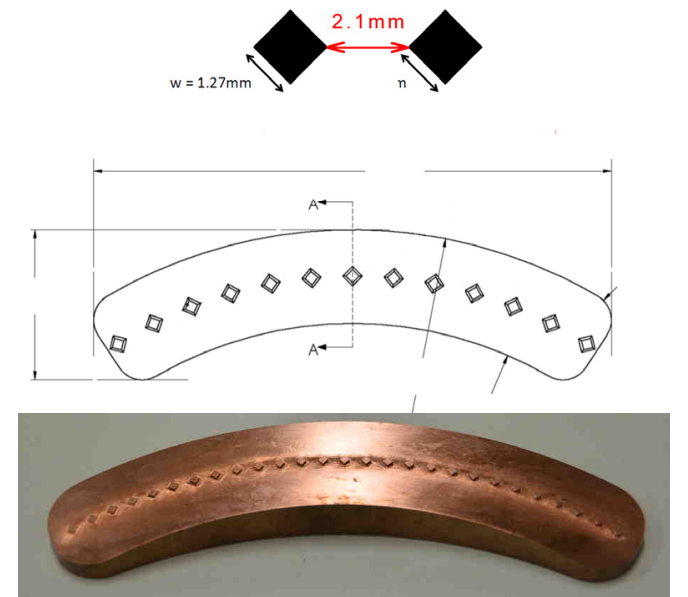

Fig.5 (Top):'Pizza box' shaped isolated roughness elements. (Bottom):A trip insert with 13 roughness elements $(\mathrm{k}=0.8 \mathrm{~mm})$ for the Apollo $\mathrm{CM}$ model. 


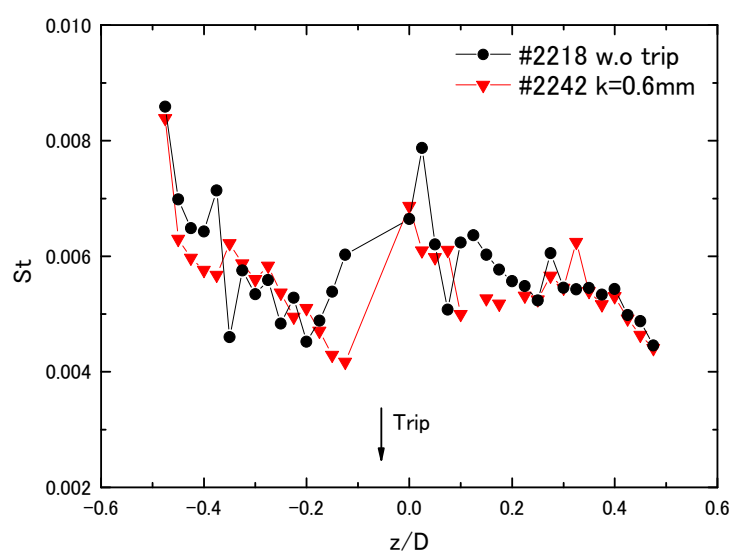

(a) $\mathrm{H}_{0}=3.5 \mathrm{MJ} / \mathrm{kg} \mathrm{P}_{0}=30 \mathrm{MPa} \mathrm{Re}=5 \times 10^{6} / \mathrm{m}$

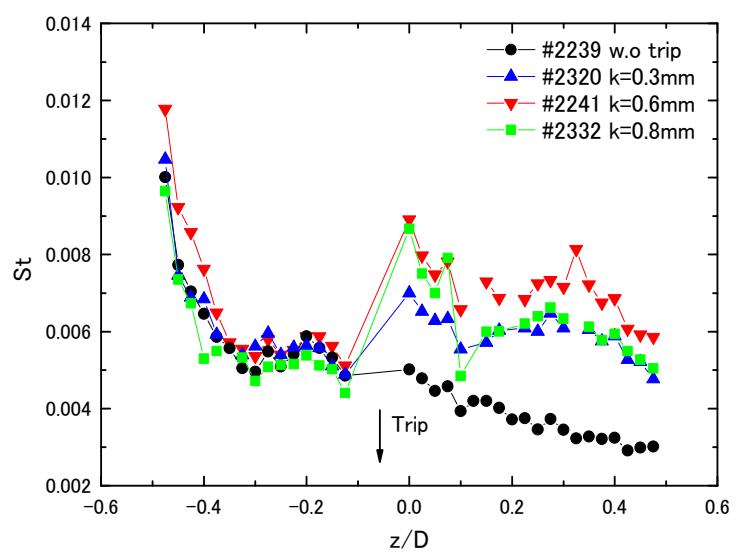

(c) $\mathrm{H}_{0}=6 \mathrm{MJ} / \mathrm{kg} \mathrm{P} \mathrm{P}_{0}=60 \mathrm{MPa} \mathrm{Re}=4 \times 10^{6} / \mathrm{m}$

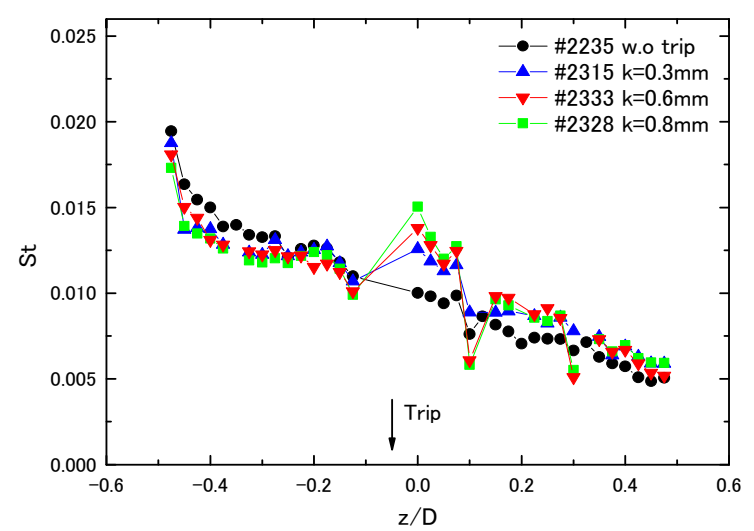

(e) $\mathrm{H}_{0}=13 \mathrm{MJ} / \mathrm{kg} \mathrm{P}=50 \mathrm{MPa} \quad \mathrm{Re}=1.5 \times 10^{6} / \mathrm{m}$

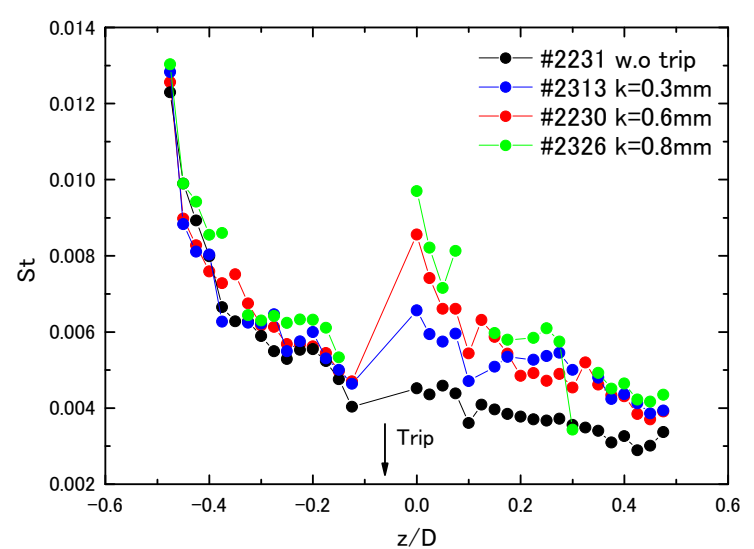

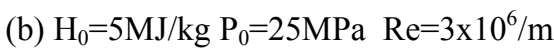

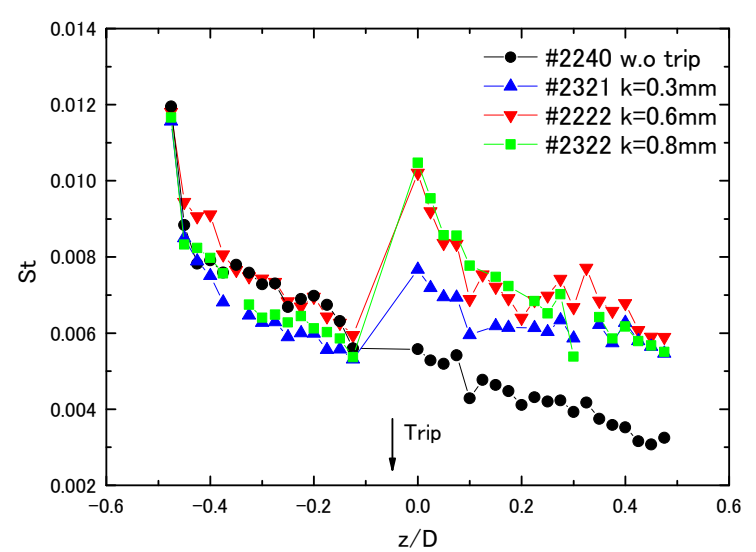

(d) $\mathrm{H}_{0}=9 \mathrm{MJ} / \mathrm{kg} \mathrm{P}=60 \mathrm{MPa} \quad \mathrm{Re}=2.5 \times 10^{6} / \mathrm{m}$

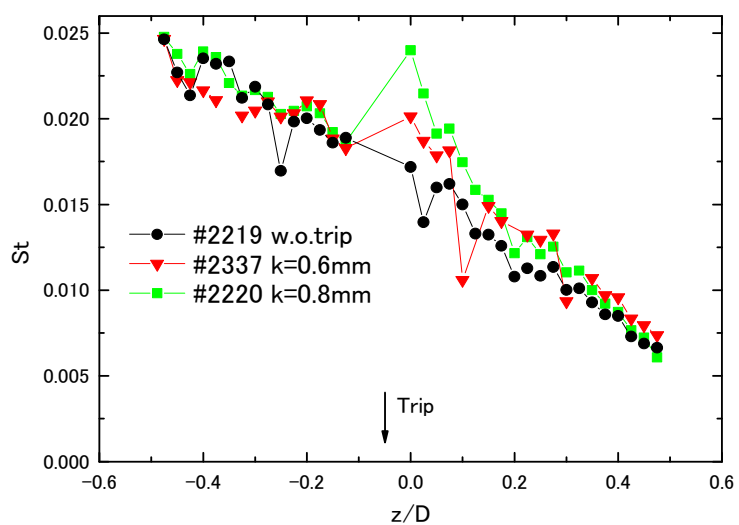

(f) $\mathrm{H}_{0}=20 \mathrm{MJ} / \mathrm{kg} \mathrm{P} \mathrm{P}_{0}=40 \mathrm{~Pa} \quad \mathrm{Re}=1 \times 10^{6} / \mathrm{m}$

Fig.6 Heat flux distribution on heat shield surface with isolated roughness elements. Test condition was varied from $\mathrm{H}_{0}=3.5$ to $13 \mathrm{MJ} / \mathrm{kg}\left(\mathrm{P}_{0}=30\right.$ to $\left.60 \mathrm{MPa}\right)$. 
used in several wind tunnel tests for CEV Orion development ${ }^{6,7,8}$. In order to mitigate machining difficulty, gap between each element was extended to $2.1 \mathrm{~mm}$ from the original $0.12 \mathrm{~mm}$ (Fig.5 top). Through numerical simulation performed in NASA JSC, boundary layer thickness on the model heat shield surface were calculated under the test flow condition operated in the HIEST previous test results ${ }^{3}$. The roughness height was determined to $\mathrm{k}=0.2,0.3,0.6$, $0.8,1.1$ and $1.3 \mathrm{~mm}$ according to the calculations. In the present test campaign, roughness height of $\mathrm{k}=0.3,0.6$ and $1.1 \mathrm{~mm}$ were applied. All the roughness elements were machined on the each trip insert made from copper alloy to prevent damage from aeroheating (Fig.5 bottom), which inserts were located $17 \mathrm{~mm}(\mathrm{z} / \mathrm{D}=0.068)$ below the model geometric centerline on the heat shield surface of the model, which location was also determined with the data reported from previous study ${ }^{8}$.

\section{Heat flux measurement}

\section{A. Miniature coaxial thermocouples}

Thermocouples used in this study were chromel-constantan thermocouples (Japanese industrial standard type-E thermocouple) with miniature co-axial configuration. The thermocouples were originally developed at CALTECH $^{9,10}$ for heat-flux measurement in the free-piston shock tunnel T5. With its microsecond response and good durability, this thermocouple is suitable for heat flux measurement in HIEST. The noteworthy feature of this thermocouple is its coaxial contact line between chromel and constantan, which provides the required durability in the harsh environment of the shock tunnel flow, in which soot and micro debris strikes its surface at extremely high speed. In the whole of the present test campaign, all of the thermocouples survived the entire test campaign including high-enthalpy high-pressure shots. The heat-flux data reduction procedure in the present test was described in the reference ${ }^{11}$. In the Stanton number shown as the following equation, the wall enthalpy of the model surface $\left(\mathrm{H}_{\text {wall }}\right)$ was hence ignored because of quite high stagnation enthalpy compared with $\mathrm{H}_{\text {wall }}$.

$$
\mathrm{S}_{\mathrm{t}}=\frac{\dot{\mathrm{q}}}{\rho_{\infty} \mathrm{u}_{\infty}\left(\mathrm{H}_{0}-\mathrm{H}_{\mathrm{wall}}\right)} \cong \frac{\dot{\mathrm{q}}}{\rho_{\infty} \mathrm{u}_{\infty}\left(\mathrm{H}_{0}\right)}
$$

\section{B. Measurement uncertainty with thermocouple}

Before the present test campaign, measurement precision with the coaxial thermocouples was evaluated. Through the several former aeroheating tests performed in HIEST, the standard deviation $\sigma$ of the Stanton number with a thermocouple was found to be $3.1 \%$. Since measurement uncertainty in wind tunnel testing is generally defined as double of standard deviation $2 \sigma$, measurement uncertainty was $\pm 6.2 \%$. In addition, individual difference of each coaxial thermocouple was also evaluated. Eleven thermocouples, which were selected from a same production lot, were mounted on a flat plate model. To obtain uniform flow condition to all the eleven thermocouples, they were densely flush-mounted on stagnation area of the model. Since a wind tunnel experiment with the flat plate model showed that the standard deviation of the thermocouples was $8.6 \%$. The precision of the measurement with the thermocouples was hence determined to $\pm 17.2 \%$.

\section{Wind tunnel test results}

\section{A. Difference between natural and forced transition}

In HIEST, stagnation conditions in the nozzle reservoir (shock tube end) were calculated with an equilibrium computation code ${ }^{12}$ from shock speed and shock tube initial condition. With the stagnation condition, free-stream condition was calculated with an axis-symmetrical JAXA in-house nozzle flow code ${ }^{13}$. Table 1 shows all the freestream conditions for the whole shots in the test campaign calculated above procedure. 
For evaluation with roughness height, heat flux distribution was discussed with the thermocouples on the centerline of heat shield surface. In the test campaign, the heat flux distribution with roughness elements were measured under $\mathrm{H}_{0}=3.5$ to $21 \mathrm{MJ} / \mathrm{kg}$ and $\mathrm{P}_{0}=16$ to $60 \mathrm{MPa}$ condition. However the shots at low stagnation pressure condition less than $\mathrm{P}_{0}=20 \mathrm{MPa}$ were not discussed in the present paper. Since heat flux measurements were remarkably changed with $\mathrm{H}_{0}$ and $\mathrm{P}_{0}$ due to unknown heat flux augmentation, they cannot be directly compared with the results obtained under different flow condition. Hence smooth surface (namely the trip insert without roughness elements) were also tested in each test condition to obtain reference heat flux distributions. The unknown heat flux augmentation will be discussed in the section IVC.

As already shown in the Fig.2, even it is limited to low enthalpy condition, HIEST can produce Re number sufficiently high enough to onset natural transition without any roughness elements. Fig. 6(a) showed a comparison between natural (smooth surface) and forced transition (roughness with $\mathrm{k}=0.6 \mathrm{~mm}$ ) measured at low enthalpy with middle pressure condition $\left(\mathrm{H}_{0}=3.5 \mathrm{MJ} / \mathrm{kg}, \mathrm{P}_{0}=30 \mathrm{MPa}\right)$, at which Unit Re number was $5 \times 10^{6} / \mathrm{m}$. It was interesting that the location of heat flux increasing point without roughness namely natural transition point was found at $\mathrm{z} / \mathrm{D}=0.16$, which was upstream from roughness element location $(\mathrm{Z} / \mathrm{D}=0.068)$. While on the heat flux distribution with the roughness elements heat flux jump were observed at $z / D=0$, which point was the closest thermocouple location downstream after the roughness. Since the location of the heat flux increasing point on smooth surface often shows dispersion even under same flow condition, it seemed reasonable of the difference in location between with or without roughness.

Since downstream from $\mathrm{z} / \mathrm{D}=0.25$, measured heat flux with and without roughness did not showed significant difference, it seemed that the boundary layer established to fully turbulent flow in both measurements. It was therefore concluded that the roughness elements was effective under the present free-stream condition and turbulent boundary layer was successfully obtained with $\mathrm{k}=0.6 \mathrm{~mm}$ roughness elements.

\section{B. Evaluation of roughness height}

The effect of roughness height under each flow condition was discussed comparing the measured heat flux distribution profiles. Fig.6(b),(c) and (d) showed the profiles of heat flux distribution up to $\mathrm{H}_{0}=9 \mathrm{MJ} / \mathrm{kg}$, which seemed to onset boundary layer transition successfully with the roughness elements. In these figures, all the roughness elements were effective

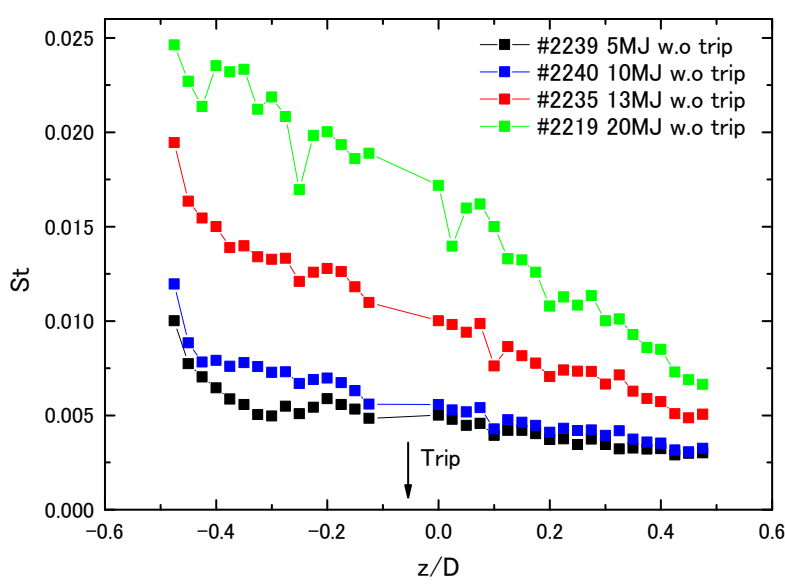

Fig.7 Summary of heat flux distribution of the Apollo $\mathrm{CM}$ model at $\mathrm{H}_{0}=3.5 \mathrm{MJ} / \mathrm{kg}$ to $18 \mathrm{MJ} / \mathrm{kg}$. All the distributions were obtained without roughness elements
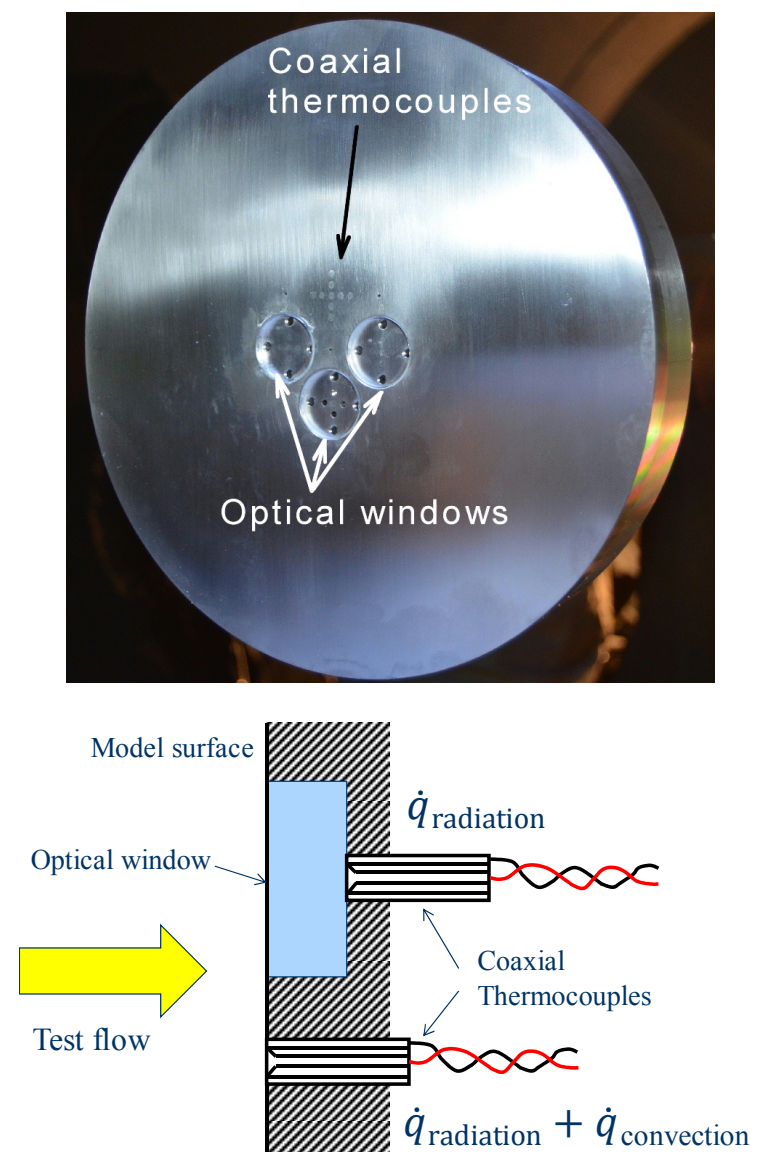

Fig.8 Top: Flat plate test model for radiation heating measurement. Bottom: Image of simple radiation power meter to measure radiation heat flux. 
because the there was no significant difference of heat flux between each roughness elements at well down stream after the roughness elements $(\mathrm{z} / \mathrm{D}=0.2$ or downstream). However, it was found that there was undesirable heat flux overshoot at downstream region nearby roughness elements. According to the comparison of heat flux distribution profiles, roughness elements with $\mathrm{k}=0.3 \mathrm{~mm}$ was the best choice because it showed minimum overshoot.

At much higher $\mathrm{H}_{0}$ condition $\left(\mathrm{H}_{0}=13 \mathrm{MJ} / \mathrm{kg}\right.$ and $\left.\mathrm{H}_{0}=20 \mathrm{MJ} / \mathrm{kg}\right)$ shown in Fig.6(e) and (f), heat flux jump was found at the vicinity of roughness elements. However, expected heat flux augmentation with turbulent boundary layer in the downstream region was not observed even with the highest roughness elements $(\mathrm{k}=0.8 \mathrm{~mm})$. Unfortunately, boundary layer onset was not successful over $\mathrm{H}_{0}=13 \mathrm{MJ} / \mathrm{kg}$ condition.

\section{Heat flux augmentation at high enthalpy}

As clearly shown in Fig.7, which is an example heat flux distribution on the heat shield, one can find the St number increased remarkably as stagnation enthalpy. This is known as unexpected heat flux augmentation under highenthalpy and high-pressure condition, which was already observed in the $\mathrm{T} 5^{8,14}$ and other major shock tunnels ${ }^{15}$. In this section, the latest results of an experimental trial to correct the augmentation were briefly described. From the measurements in pervious study ${ }^{16}$ it was suspected that the augmentation would be caused by unknown radiation, even general theories and some computations told radiation heating was negligible under HIEST stagnation conditions because of its low temperature ( up to $10000 \mathrm{~K})$. To examine the unknown radiation heating, a preliminary wind tunnel test campaign with a generic test model was conducted in the HIEST. A test model was a simple 10inch-diameter flat plate with miniature coaxial thermocouples instrumented on the front surface. As shown in the schematic of the model surface (Fig.8), the special feature of the model was transparent glass windows (Made of UV grade Fused Silica- $\mathrm{SiO}_{2}$ ) placed in front of some of the thermocouples, which worked as optical filters to cut off convection heating. Namely, the thermocouples with the windows sensed radiation heating only, while those without the windows did both convection and radiation heating. Fig. 9 showed a typical result measured with this flat plate model at $\mathrm{H}_{0}=20 \mathrm{MJ} / \mathrm{kg}$ and $\mathrm{P}_{0}=45 \mathrm{Mpa}$. It should be noted that the remarkable radiation heat flux (over $10 \mathrm{MW} / \mathrm{m}^{2}$ ) was measured through the optical window, which heat flux was almost $40 \%$ of heat flux measured without window. It should be also noted that the delay of jump-up time of heat flux through the window implied that the radiation heating came from shock layer. Ratio of heat flux through the window and without window was plotted in Fig. 10 at $\mathrm{H}_{0}=8 \mathrm{MJ} / \mathrm{kg}$ to $20 \mathrm{MJ} / \mathrm{kg}$ and at approximately constant $\mathrm{P}_{0}$ (approximately $50 \mathrm{MPa}$ ). Due to limited number of shots in this small experimental trial, further discussion cannot be made. Moreover, the present heat flux measurement was limited at the stagnation point of the simple flat plate model, precise correction to the whole of the Apollo heat shield surface is not possible. However, the results concluded that measured heat flux in HIEST should be reduced as the correlation depicted in the figure accordingly.

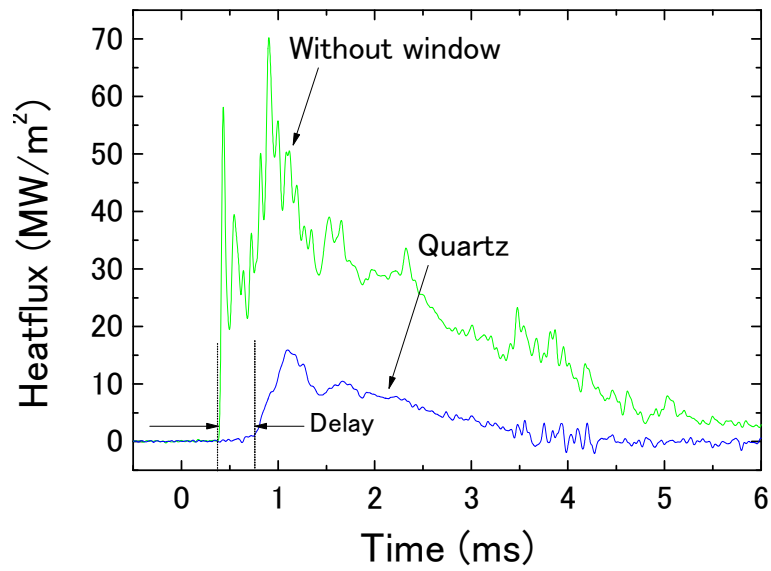

Fig.9 Surface and radiation heat flux on the flat plate model at $\mathrm{H}_{0}=\mathbf{2 0 M J} / \mathrm{kg}$ and $\mathrm{P}_{0}=45 \mathrm{MPa}$.

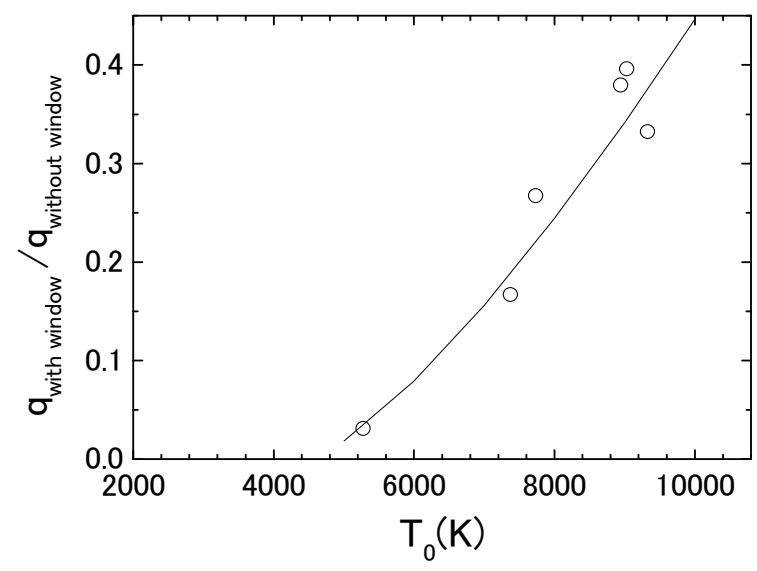

Fig.10 Ratio of radiation heat flux and surface heat flux related to stagnation temperature. Solid line is a polynomial fitting curve. 


\section{Summary}

The heat flux of a $6.4 \%$ scaled Apollo capsule model was measured in HIEST under high-enthalpy high-Reynolds number conditions. To obtain heat flux under turbulent boundary layer condition, trip insert with isolated roughness $\mathrm{k}=0.3 \mathrm{~mm}, 0.6 \mathrm{~mm}$ and $0.8 \mathrm{~mm}$ was mounted on the heat shield side of the model. Heat flux was measured at angles of attack of $28^{\circ}$, and measured heat flux was normalized to the Stanton number. Heat flux with turbulent boundary layer with the roughness elements was successfully measured at stagnation enthalpy up to $9 \mathrm{MJ} / \mathrm{kg}$, at which $\mathrm{Re}$ number based on model diameter was 0.7 milion. Additional experiments to correct the unexpected heating augmentation, which was remarkable under high-enthalpy high-pressure condition, were also conducted.

\section{Acknowledgement}

The authors wish to thank Mr.Fujimura for the cooperation on data reduction for the whole shots in this test campaign.

\section{References}

${ }^{1}$ Itoh, K., Ueda, S., Tanno, H., Komuro, T. and Sato, K., "Hypersonic Aerothermodynamic and Scramjet Research Using High Enthalpy Shock Tunnel,” Shock Waves, Vol.12, 93-98, 2002.

${ }^{2}$ Hornung, H.G. and Belanger, J., "Role and techniques of ground testing for simulation of flows up to orbital speed", AIAA Paper No.1990-1377.

${ }^{3}$ Tanno, H., Komuro, T. and Sato, K., Itoh, K., Yamada, T., Sato, N. and Nakano, H., "Heat flux measurement of Apollo capsule model in the free-piston shock tunnel HIEST", AIAA Paper No.2009-7304.

${ }^{4}$ Lee,D.B., Bertin, J.J., and Goodrich, W.D., "Heat-transfer rate and pressure measurements obtained during Apollo orbital entries, NASA TN D-6028.

${ }^{5}$ Hollis, B.R., Berger, K.T., Horvath, T.J., Coblish, J.J., Norris, J.D., Lillard, R.P., and Kirk, B.S., “Aeroheating testing and prediction for project Orion CEV at turbulent condition", AIAA Paper No.2008-1226.

${ }^{6}$ Amar, A.J., Horvath, T.J., Hollis, B.R., Berger, K.T., Berry, S.A., "Protuberance boundary layer transition for project Orion crew entry vehicle", AIAA Paper No.2008-1227.

${ }^{7}$ Berger, K.T., "Aerothermodynamic Testing of the Crew Exploration Vehicle in the LaRC 20-Inch Mach 6 and 31-Inch Mach 10 tunnels", AIAA Paper No.2008-1225.

${ }^{8}$ Marineau, E.C., Laurence, S.J. and Hornung, H.G., "Apollo-shaped capsule boundary layer transition at high-enthalpy in T5", AIAA Paper No.2010-446.

${ }^{9}$ Sanderson,S. and Sturtevant, B., "Transient heat flux measurement using a surface junction thermocouple”, Rev.Sci.Inst., Vol.73, No.7, 2002

${ }^{10}$ Marineau, E.C. and Hornung, H.G., "Modeling and Calibration of Fast-Response Coaxial Heat Flux Gages”, AIAA Paper No. 2009-737.

${ }^{11}$ Schultz, D.L. and Jones, T.V., "Heat transfer measurements in short duration hypersonic facilities", AGARDograph 165, 1973.

${ }^{12}$ Prabhu, RK., and Erickson WD.,"A Rapid Method for the Computation of Equilibrium Chemical Composition of Air to 15000K”, NASA TP-2792, 1988.

${ }^{13}$ Takahashi, M., et.al., "Influence of Thermal Non-Equilibrium on Nozzle Flow Condition of High Enthalpy Shock Tunnel HIEST ”, AIAA Paper No.2009-7267.

${ }^{14}$ Olenjniczak, J., Wright, M.J., Laurence, S. and Hornung, H.G., "Computational Modeling of T5 Laminar and Turbulent Heating Data on Blunt Cones, Part 1: Titan Applications," AIAA Paper No. 2005-176.

${ }^{15}$ Hollis, B.R. and Prabhu, D.K., "Assessment of Laminar, Convective Aeroheating Prediction Uncertainties for Mars Entry Vehicles," AIAA Paper No. 2011-3144.

${ }^{16}$ Tanno, H., Komuro, T., Sato, K. and Itoh, K., "Heat flux anomaly in high enthalpy and high Reynolds number flow", AIAA Paper No.2012-3104. 


\begin{tabular}{|c|c|c|c|c|c|c|c|c|c|c|c|}
\hline Shot & $\mathrm{k}(\mathrm{mm})$ & $\mathrm{P}_{0}(\mathrm{MPa})$ & $\mathrm{H}_{0}(\mathrm{MJ} / \mathrm{kg})$ & $\mathrm{T}_{0}(\mathrm{~K})$ & $\mathrm{T}_{\infty}(\mathrm{K})$ & $\mathrm{P}_{\infty}(\mathrm{kPa})$ & $\rho_{\infty}\left(\mathrm{kg} / \mathrm{m}^{3}\right)$ & $\mathrm{u}_{\infty}(\mathrm{m} / \mathrm{s})$ & $M_{\infty}$ & $\gamma$ & Unit $\operatorname{Re}(1 / \mathrm{m})$ \\
\hline 2216 & 0.0 & 31.867 & 6.215 & 4402.0 & 576.1 & 3.531 & 0.02120 & 3290.1 & 6.869 & 1.378 & $2.4 \mathrm{E}+06$ \\
\hline 2217 & 0.0 & 32.394 & 7.332 & 4894.0 & 728.4 & 3.985 & 0.01887 & 3553.4 & 6.627 & 1.362 & $1.9 \mathrm{E}+06$ \\
\hline 2218 & 0.0 & 31.076 & 3.638 & 2976.0 & 274.9 & 2.531 & 0.03194 & 2547.4 & 7.653 & 1.398 & $4.8 \mathrm{E}+06$ \\
\hline 2219 & 0.0 & 41.594 & 18.074 & 8536.0 & 1802.6 & 6.532 & 0.01136 & 5297.3 & 6.038 & 1.338 & $9.5 \mathrm{E}+05$ \\
\hline 2220 & 0.8 & 41.543 & 20.755 & 9040.0 & 2007.5 & 6.679 & 0.01012 & 5635.5 & 5.981 & 1.346 & $8.4 \mathrm{E}+05$ \\
\hline 2221 & 0.8 & 60.015 & 9.394 & 5861.0 & 1024.9 & 8.381 & 0.02808 & 3992.7 & 6.322 & 1.336 & $2.6 \mathrm{E}+06$ \\
\hline 2222 & 0.6 & 58.404 & 9.193 & 5770.0 & 996.7 & 8.076 & 0.02784 & 3953.6 & 6.346 & 1.338 & $2.6 \mathrm{E}+06$ \\
\hline 2223 & 0.6 & 45.708 & 12.189 & 6921.0 & 1333.4 & 6.888 & 0.01730 & 4462.4 & 6.137 & 1.328 & $1.5 \mathrm{E}+06$ \\
\hline 2224 & 0.6 & 25.352 & 11.883 & 6647.0 & 1212.7 & 3.670 & 0.01002 & 4376.8 & 6.250 & 1.338 & $9.0 \mathrm{E}+05$ \\
\hline 2225 & 0.6 & 15.422 & 10.017 & 5801.0 & 985.1 & 2.118 & 0.00718 & 4035.5 & 6.396 & 1.349 & $6.9 \mathrm{E}+05$ \\
\hline 2226 & 0.6 & 15.209 & 13.452 & 7034.0 & 1216.4 & 2.097 & 0.00550 & 4577.7 & 6.378 & 1.352 & $5.2 E+05$ \\
\hline 2227 & 0.6 & 16.111 & 3.175 & 2659.0 & 232.9 & 1.261 & 0.01878 & 2389.4 & 7.798 & 1.398 & $3.0 \mathrm{E}+06$ \\
\hline 2228 & 0.6 & 13.740 & 4.695 & 3592.0 & 385.8 & 1.306 & 0.01173 & 2870.7 & 7.283 & 1.395 & $1.5 \mathrm{E}+06$ \\
\hline 2229 & 0.6 & 29.810 & 14.267 & 7481.0 & 1428.8 & 4.419 & 0.01000 & 4750.3 & 6.181 & 1.337 & $8.8 E+05$ \\
\hline 2230 & 0.6 & 26.831 & 5.133 & 3859.0 & 438.0 & 2.640 & 0.02089 & 3003.2 & 7.162 & 1.391 & $2.6 \mathrm{E}+06$ \\
\hline 2231 & 0.0 & 26.770 & 4.830 & 3696.0 & 402.2 & 2.540 & 0.02189 & 2917.1 & 7.254 & 1.393 & $2.8 \mathrm{E}+06$ \\
\hline 2232 & 0.0 & 12.716 & 4.633 & 3555.0 & 378.6 & 1.202 & 0.01100 & 2851.7 & 7.302 & 1.395 & $1.4 \mathrm{E}+06$ \\
\hline 2233 & 0.0 & 15.442 & 2.984 & 2525.0 & 216.0 & 1.179 & 0.01893 & 2322.0 & 7.868 & 1.398 & $3.1 \mathrm{E}+06$ \\
\hline 2234 & 0.0 & 29.921 & 13.090 & 7117.0 & 1340.6 & 4.417 & 0.01081 & 4575.6 & 6.193 & 1.335 & $9.5 \mathrm{E}+05$ \\
\hline 2235 & 0.0 & 43.195 & 12.797 & 7125.0 & 1383.9 & 6.538 & 0.01571 & 4554.5 & 6.125 & 1.329 & $1.4 \mathrm{E}+06$ \\
\hline 2236 & 0.0 & 14.378 & 14.361 & 7274.0 & 1252.9 & 1.968 & 0.00494 & 4705.3 & 6.404 & 1.355 & $4.7 \mathrm{E}+05$ \\
\hline 2237 & 0.0 & 14.773 & 9.827 & 5716.0 & 963.4 & 2.016 & 0.00700 & 3999.9 & 6.412 & 1.351 & $6.7 \mathrm{E}+05$ \\
\hline 2238 & 0.0 & 24.713 & 11.585 & 6529.0 & 1183.7 & 3.563 & 0.00999 & 4327.4 & 6.262 & 1.339 & $9.0 \mathrm{E}+05$ \\
\hline 2239 & 0.0 & 55.638 & 6.406 & 4553.0 & 603.3 & 6.203 & 0.03561 & 3345.6 & 6.838 & 1.374 & $3.9 \mathrm{E}+06$ \\
\hline 2240 & 0.0 & 51.605 & 8.963 & 5646.0 & 961.5 & 7.054 & 0.02521 & 3905.3 & 6.376 & 1.341 & $2.4 \mathrm{E}+06$ \\
\hline 2241 & 0.6 & 52.436 & 6.259 & 4476.0 & 583.1 & 5.765 & 0.03425 & 3308.3 & 6.872 & 1.377 & $3.8 \mathrm{E}+06$ \\
\hline 2242 & 0.6 & 29.891 & 3.587 & 2942.0 & 270.0 & 2.421 & 0.03110 & 2530.5 & 7.670 & 1.398 & $4.7 \mathrm{E}+06$ \\
\hline 2243 & 0.6 & 46.974 & 13.212 & 7293.0 & 1438.0 & 7.181 & 0.01657 & 4623.4 & 6.097 & 1.327 & $1.4 \mathrm{E}+06$ \\
\hline 2244 & 0.0 & 48.940 & 14.445 & 7699.0 & 1558.9 & 7.589 & 0.01597 & 4809.8 & 6.058 & 1.327 & $1.3 \mathrm{E}+06$ \\
\hline 2310 & 0.3 & 16.942 & 3.345 & 2776.0 & 247.0 & 1.331 & 0.01869 & 2448.2 & 7.758 & 1.398 & $2.9 \mathrm{E}+06$ \\
\hline 2311 & 0.3 & 14.236 & 5.209 & 3855.0 & 442.8 & 1.414 & 0.01105 & 3015.9 & 7.147 & 1.391 & $1.4 \mathrm{E}+06$ \\
\hline 2312 & 0.3 & 30.519 & 3.609 & 2957.0 & 271.0 & 2.441 & 0.03124 & 2538.2 & 7.680 & 1.398 & $4.7 \mathrm{E}+06$ \\
\hline 2313 & 0.3 & 26.730 & 4.813 & 3687.0 & 398.8 & 2.496 & 0.02170 & 2912.7 & 7.274 & 1.394 & $2.8 \mathrm{E}+06$ \\
\hline 2314 & 0.3 & 32.292 & 15.298 & 7792.0 & 1512.5 & 4.732 & 0.01002 & 4905.5 & 6.173 & 1.338 & $8.7 E+05$ \\
\hline 2315 & 0.3 & 48.403 & 14.331 & 7661.0 & 1535.5 & 7.316 & 0.01564 & 4794.3 & 6.085 & 1.328 & $1.3 \mathrm{E}+06$ \\
\hline 2316 & 0.3 & 15.979 & 10.374 & 5951.0 & 1014.0 & 2.162 & 0.00710 & 4099.9 & 6.396 & 1.348 & $6.7 \mathrm{E}+05$ \\
\hline 2317 & 0.3 & 25.402 & 11.192 & 6385.0 & 1146.4 & 3.572 & 0.01039 & 4266.9 & 6.289 & 1.339 & $9.5 \mathrm{E}+05$ \\
\hline 2318 & 0.3 & 15.594 & 14.521 & 7342.0 & 1273.4 & 2.107 & 0.00521 & 4736.7 & 6.400 & 1.354 & $4.9 \mathrm{E}+05$ \\
\hline 2319 & 0.3 & 15.898 & 14.944 & 7457.0 & 1300.9 & 2.151 & 0.00518 & 4798.7 & 6.397 & 1.355 & $4.9 \mathrm{E}+05$ \\
\hline 2320 & 0.3 & 60.359 & 6.506 & 4610.0 & 614.4 & 6.670 & 0.03760 & 3372.0 & 6.832 & 1.373 & $4.1 \mathrm{E}+06$ \\
\hline 2321 & 0.3 & 59.285 & 9.417 & 5868.0 & 1021.9 & 8.115 & 0.02726 & 3998.0 & 6.338 & 1.337 & $2.5 \mathrm{E}+06$ \\
\hline 2322 & 0.8 & 60.248 & 9.250 & 5801.0 & 1000.1 & 8.181 & 0.02811 & 3966.8 & 6.357 & 1.338 & $2.6 \mathrm{E}+06$ \\
\hline 2323 & 0.8 & 16.364 & 3.272 & 2726.0 & 240.4 & 1.274 & 0.01838 & 2423.4 & 7.785 & 1.398 & $2.9 \mathrm{E}+06$ \\
\hline 2324 & 0.8 & 13.152 & 4.990 & 3742.0 & 417.1 & 1.277 & 0.01059 & 2954.5 & 7.211 & 1.393 & $1.3 \mathrm{E}+06$ \\
\hline 2325 & 0.8 & 30.712 & 3.685 & 3007.0 & 278.3 & 2.482 & 0.03093 & 2563.3 & 7.653 & 1.398 & $4.6 \mathrm{E}+06$ \\
\hline 2326 & 0.8 & 23.092 & 4.359 & 3423.0 & 348.0 & 2.051 & 0.02044 & 2775.8 & 7.414 & 1.396 & $2.8 \mathrm{E}+06$ \\
\hline 2327 & 0.8 & 32.556 & 13.899 & 7400.0 & 1412.1 & 4.747 & 0.01095 & 4704.3 & 6.184 & 1.335 & $9.6 \mathrm{E}+05$ \\
\hline 2328 & 0.8 & 49.507 & 14.338 & 7671.0 & 1541.2 & 7.499 & 0.01599 & 4796.7 & 6.079 & 1.327 & $1.3 \mathrm{E}+06$ \\
\hline 2329 & 0.8 & 16.171 & 10.686 & 6077.0 & 1040.5 & 2.196 & 0.00700 & 4152.6 & 6.386 & 1.348 & $6.6 \mathrm{E}+05$ \\
\hline 2330 & 0.8 & 15.695 & 14.982 & 7462.0 & 1299.5 & 2.119 & 0.00510 & 4803.0 & 6.402 & 1.355 & $4.8 \mathrm{E}+05$ \\
\hline 2331 & 0.8 & 27.196 & 11.214 & 6411.0 & 1157.9 & 3.840 & 0.01108 & 4274.9 & 6.277 & 1.338 & $1.0 E+06$ \\
\hline 2332 & 0.8 & 60.086 & 6.543 & 4627.0 & 619.6 & 6.668 & 0.03728 & 3381.0 & 6.823 & 1.373 & $4.1 \mathrm{E}+06$ \\
\hline 2333 & 0.6 & 48.109 & 14.206 & 7621.0 & 1523.2 & 7.261 & 0.01567 & 4775.6 & 6.089 & 1.328 & $1.3 \mathrm{E}+06$ \\
\hline 2334 & 0.6 & 58.981 & 9.434 & 5874.0 & 1023.9 & 8.081 & 0.02709 & 4001.0 & 6.336 & 1.337 & $2.5 \mathrm{E}+06$ \\
\hline 2335 & 0.6 & 45.221 & 21.548 & 9218.0 & 2090.2 & 7.233 & 0.01048 & 5739.5 & 5.954 & 1.346 & $8.6 \mathrm{E}+05$ \\
\hline 2336 & 0.6 & 45.191 & 22.031 & 9297.0 & 2132.2 & 7.269 & 0.01027 & 5797.3 & 5.937 & 1.348 & $8.4 E+05$ \\
\hline 2337 & 0.6 & 42.931 & 20.300 & 8977.0 & 1968.8 & 6.742 & 0.01048 & 5583.7 & 6.005 & 1.344 & $8.7 \mathrm{E}+05$ \\
\hline
\end{tabular}

Table.1 Free-stream parameters of the Apollo test campaign. The parameters were calculated with a JAXA in-house code $^{7}$. 